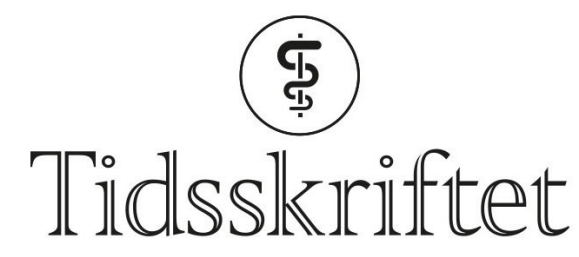

DEN NORSKE LEGEFORENING

\title{
Kilder til kunnskap
}

MINILEDER

\section{ARE BREAN}

Sjefredaktør

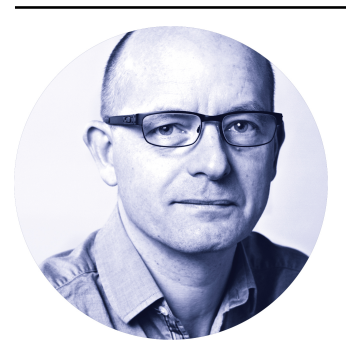

De mange norske helseregistrene, helseundersøkelsene og andre befolkningsbaserte helsedata er unike kilder for mange typer forskning. Men for forskere som ønsker å koble data fra flere slike kilder, har tilgangen vært frustrerende komplisert og tidkrevende. Nå har regjeringen vedtatt å bruke 150 millioner kroner på å forenkle tilgangen. Den nye «helseanalyseplattformen» skal gjøre det enklere å foreta analyser på tvers.

At «data er den nye oljen» har på kort tid rukket å bli et forslitt uttrykk. Men for registerbasert helseforskning kan det vise seg å være noe sannhet i det likevel. For det finnes neppe noe annet land i verden som har så mange og gode kilder til befolkningsbaserte helsedata som Norge. Enklere tilgang vil bety mye for muligheten til å utnytte disse kildene enda bedre - for å skaffe kunnskap som kan føre til bedre helse.

Publisert: 28. mai 2018. Tidsskr Nor Legeforen. DOI:10.4045/tidsskr.18.o9.01

(C) Tidsskrift for Den norske legeforening 2020. Lastet ned fra tidsskriftet.no 